\title{
Effect of Climate Variables in Rice Yield in Nueva Ecija, Philippines
}

\section{Andro M. Enovejas ${ }^{1}$, Sharmaine Maldia ${ }^{1}$, Nurul Amri Komarudin ${ }^{2 *}$, Yahya Shafiyuddin Hilmi ${ }^{3}$ Dante Gideon K. Vergara ${ }^{1}$, and Janice B. Sevilla-Nastor ${ }^{1}$}

\author{
${ }^{1}$ School of Environmental Science and Management, University of the Philippines Los Baños, \\ College, Los Baños, Philippines 4031 \\ ${ }^{2}$ Natural Resources and Environmental Management Sciences, Graduate School, IPB University, Kampus IPB \\ Baranangsiang, Bogor Timur, Bogor City, West Java 16129, Indonesia \\ ${ }^{3}$ Department of Agricultural Socio-economics, Faculty of Agriculture, Universitas Gadjah Mada, Sleman, Special Region of \\ Yogyakarta 55281, Indonesia
}

*Corresponding Author's E-mails address: amrigfm49@gmail.com

\begin{abstract}
Climate variability is one of the factors that directly and greatly affect cropping system and plant yield. It is therefore very important to obtain a good understanding about climate variability or changes in the climate and the effect of these changes to clearly understand the vulnerability of food crops as well as its agronomic impacts for us to create and implement adaptive strategies to mitigate its negative effects. This study assessed the effect of climate in rice crop yield in both irrigated and rainfed ecotype farming system in Nueva Ecija Province in the Philippines using semi-annual yield data and the different climate variables such as seasonal rainfall, mean temperature, minimum temperature, and relative humidity by using empirical/statistical method through time series analysis, and correlation analysis. Results indicated that rice yield for irrigated and rainfed ecosystem type of farming in Nueva Ecija show an overall increasing trend from year 1991-2018, although there are observed decline and fluctuations in some years. The different climate variables (i.e., rainfall, temperature, and humidity) show fluctuating trends and irregularities spanning from the year 1991-2018. But it showed overall decreasing trends for relative humidity and increasing trends for rainfall, minimum temperature, and mean temperature. There are significant correlations between rice yield the all the climate variables in both irrigated and rainfed farming ecosystem types. For irrigated ecotype, rainfall and relative humidity have negative correlation to yield while positive correlation for mean temperature and minimum temperature. On the other, for rainfed ecotype, rainfall, minimum temperature, and relative humidity have positive correlation to yield while negative correlation for mean temperature. Based on GIS mapping, Nueva Ecija is reported for having low average annual rainfall and relative humidity. However, the average annual rice production and yield in both irrigated and rainfed farming systems were found as the highest compared to the other province in Central Luzon.
\end{abstract}

Keywords - Climate variability, irrigated, rainfed, rice crop yield.

\section{INTRODUCTION}

Rice (Oryza sativa $L$ ) is one of the most important human food crops in the world, directly feeding more people than any other crop. It is the main staple food in Asia (particularly in southern and eastern Asia), where about $90 \%$ of the world's rice is produced and consumed according to the Ricepedia (2019). One of these Asian countries that produce rice in a bigger volume is the Philippines. Philippines produced a total of around 19.07 million metric tons (MMT) in the year 2018 (PSA, 2019) Central Luzon made the highest contribution. of $3.61 \mathrm{MMT}$, or 18.96 percent to the total rice production in 2018. Nueva Ecija, one of the provinces in Central Luzon is recognized as the "Rice Granary" of the region because it led the production of the region's as well as the whole nation's food staple during the twentieth century until the present (Figure 1). According to the Philippine Statistic Authority (2019) Nueva Ecija contributed 1.89 MMT or $51.92 \%$ of Central Luzon's and $9.91 \%$ of the country's rice production in the year 2018 . 


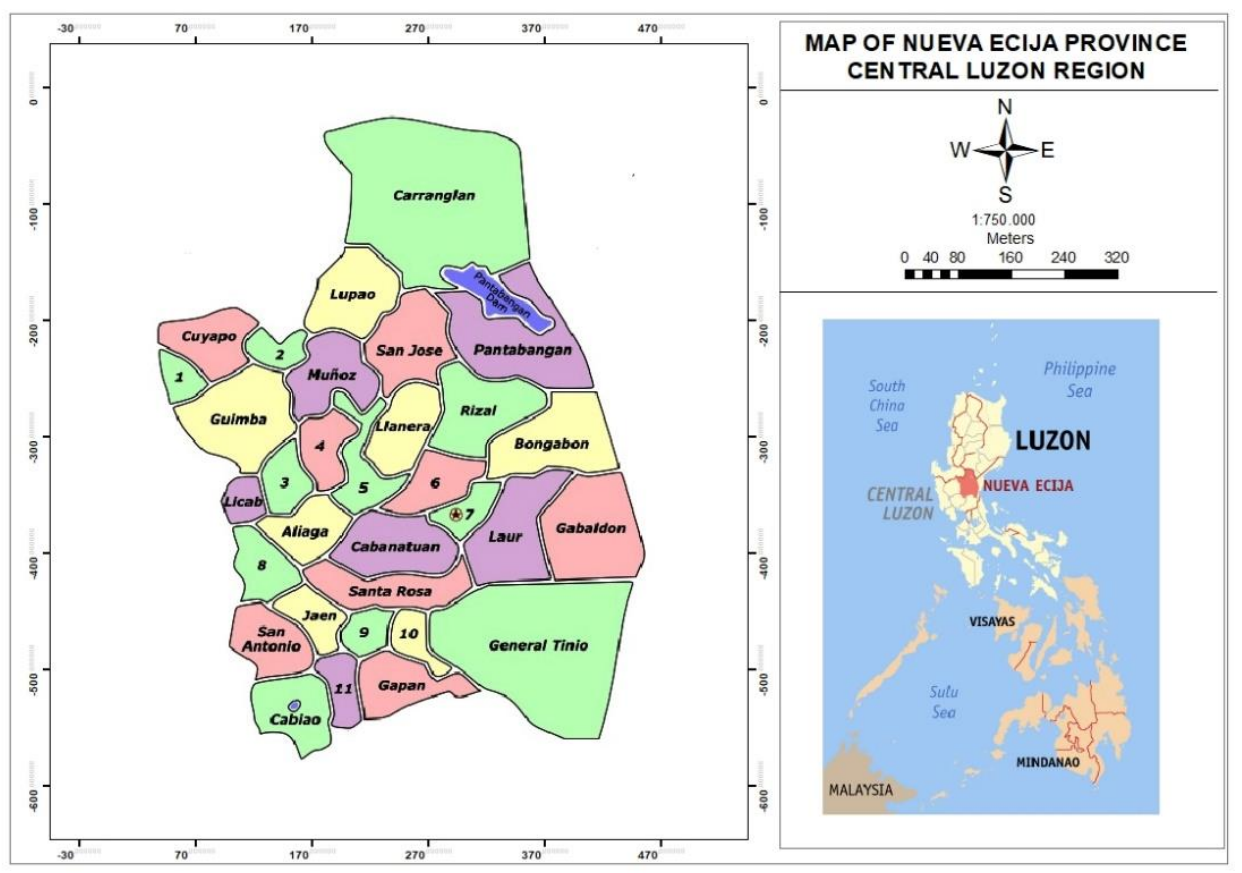

Fig. 1. Map of Nueva Ecija Province, Central Luzon Region, Philippines

According to UNESCO (2019) Nueva Ecija is considered 'The Rice Granary of the Philippines' because it is from this province that the Philippines sources its biggest supply of rice grains and byproducts, with its wealthiest citizens being rice millers, dealers and merchants. Despite the increased industrialization of many developing countries, Nueva Ecija remains dependent on its strong agricultural economy. Nueva Ecija employs both rainfed and irrigated rice-based agriculture. Irrigated rice is being grown in an area with irrigation facilities that supply water to the farm through gravity, force/power, pump, etc. While rainfed rice is being grown in an ecosystem that has dikes that retain water and is solely dependent upon rainfall for its water supply. Based in PSA record in the year 2018, there have been 1.74 million MT of irrigated rice produced during the said year while rainfed rice production is around $147,000 \mathrm{MT}$. Being the largest producer of rice in the Philippines and being strongly dependent on agricultural economy, understanding what drives changes in rice production in Nueva Ecija is essential for meeting current and future food security in the said province and the whole Philippines as well.

Variations in rice crop production and yield can be caused and driven by different factors. It can be explained by either endogenous drivers such as genetics and agronomy (Specht et al. 1999; Tollenser et al. 2002) and exogenous factors such as climate variability (Bell et al. 1995). Climate variability and climate change could drastically change local environments, damage yields (Leak et al. 2016; Batisti et al. 2009) and influence the yield stability of staple crops (Urban et al. 2015; Lizumi et al. 2016). According to Lansigan et al. (2000) weather and climate have direct influence on cropping systems and plant yield. Thus, weather fluctuations and climate variability play significant role in crop growth and yield. Occurrence of abnormal weather episodes during the growing season or during critical development stages may hamper growth processes resulting in yield reduction. Additionally, weather, as a short-term of climate change, can also affect yield by inducing changes in temperature, potential evapotranspiration, and moisture availability (Lansigan et al. 2000). It is therefore very important to obtain a good understanding about climate variability or changes in the climate and the effect of these changes on the growth and development of crops since a clear understanding of the vulnerability of food crops as well as the agronomic impacts of climate variability will enable one to implement adaptive strategies to mitigate its negative effects (Matthews et al. 2003).

Many studies that used information about yieldclimate relationship which can be used to evaluate the impacts of climate variabilities on rice production have already been done. Information about yield-climate relationship can provide basis 
for within-year-crop forecasting, and projecting impact of future climate change (Lobell et al. 2007). Yield-climate relationship can be derived using either biophysical models such as eco physiological models or empirical/statistical method (Lobell et al.

\section{METHODOLOGY}

\section{A. Data Acquisition}

Rice production data from 1991-2018 were obtained from the Philippine Statistics Authority (PSA), (http://countrystat.psa.gov.ph/) for the province of Nueva Ecija. Area harvested (hectares, Ha) and production volume (metric tons, MT) data were also obtained for each quarter, semester and year, for both irrigated and rainfed rice production. Yield (MT/Ha) was calculated by dividing the production volume (MT) by the area harvested (Ha). Monthly rainfall $(\mathrm{mm} / \mathrm{month})$, mean temperature $\left({ }^{\circ} \mathrm{C}\right)$, average minimum temperature $\left({ }^{\circ} \mathrm{C}\right)$ and relative humidity (\%) from 1991-2018 were obtained from the Philippine Atmospheric Geophysical and Astronomical Services Administration (PAGASA) (http://bagong.pagasa.dost.gov.ph /climate/climatedata) for the five synoptic stations in Central Luzon namely Baler and Casiguran in Aurora province, Clark in Pampanga, Iba in Zambales and Cabanatuan which is located in Nueva Ecija. Summation of monthly rainfall data was done to get the annual (mm/year), quarter (mm/quarter) and semi-annual ( $\mathrm{mm} / \mathrm{semester)} \mathrm{data} \mathrm{for} \mathrm{rainfall.} \mathrm{On} \mathrm{the} \mathrm{other} \mathrm{hand,}$ averaging method was done to get each annual, quarterly and semi-annual data for minimum, mean temperature, and relative humidity. Map coordinates (latitude and longitude) for the five synoptic stations were generated using Geospatial Information System (GIS) mapping using QGIS and ArcGIS software were obtained from GeoDatos website (https://www.geodatos.net/en).

\section{B. Statistical Data Analysis}

For statistical data analysis, linear model trend (equation 1) was fitted to yield, rainfall, mean
2010; Salvacion 2019). The main objective of this study investigates the effects of varying climatic conditions in the production of rice crops in Nueva Ecija, Philippines.

temperature, mean diurnal temperature range and relative humidity time series with 4-year/period moving average (as a smoothing method) for Nueva Ecija for both irrigated and rainfed ecosystem farming type and for annual, semi-annual, and quarterly data. Correlation analysis was also done to determine the relationship of yield to different climate variables.

$$
Y_{t}=\alpha+\beta t
$$

where:

$$
\begin{aligned}
Y_{\mathrm{t}} & =\text { dependent variable } \\
\mathrm{t} & =\text { time index. } \\
\alpha & =\text { intercept of the trend line } \\
\beta & =\text { the slope of the trend line }
\end{aligned}
$$

Rice production and climate anomalies such as rainfall/precipitation and mean temperature anomalies as observed in the time series graphs from 1991-2018 were computed from the annual rice production, rainfall, and mean temperature data from 1991-2018 and the long term (30-year) average annual rice production from 1988-2018 and rainfall and mean temperature data from 1985-2015. Graphs were generated using MS excel.

\section{GIS Mapping}

Mapping of the annual rice production, annual rainfall, and annual temperature in Nueva Ecija was carried out using QGIS 10.3 and ArcGIS 10.5 software. QGIS is used to identify synoptic station points where the station is located in Baler and Casiguran in Aurora province, Clark in Pampanga province, Iba in Zambales province after spatial

\begin{tabular}{|c|c|c|c|c|c|c|c|c|c|}
\hline \multicolumn{2}{|c|}{ COORDINAT } & \multirow{2}{*}{$\mathrm{ST}$} & \multirow{2}{*}{$\begin{array}{c}\text { AAR } \\
(\mathrm{mm} / \mathrm{yr})\end{array}$} & \multirow{2}{*}{$\begin{array}{c}\text { AATM } \\
\left({ }^{\circ} \mathrm{C}\right) \\
\end{array}$} & \multirow{2}{*}{$\begin{array}{c}\text { AARH } \\
(\%)\end{array}$} & \multirow{2}{*}{$\begin{array}{c}\text { AAIRP } \\
\text { (MT) }\end{array}$} & \multirow{2}{*}{$\begin{array}{c}\text { AARRP } \\
(\mathrm{MT})\end{array}$} & \multirow{2}{*}{$\begin{array}{c}\text { AAIRY } \\
\text { (MT/Ha) }\end{array}$} & \multirow{2}{*}{$\begin{array}{l}\text { AARRY } \\
(\mathrm{MT} / \mathrm{Ha})\end{array}$} \\
\hline $\mathbf{X}$ & $\mathbf{Y}$ & & & & & & & & \\
\hline 15.4858 & 120.9664 & Cabanatuan & 1767 & 28.4 & 83.7 & 1087122 & 1322988 & 228197 & 41458 \\
\hline 15.3329 & 119.9757 & Iba & 2583 & 28.5 & 80.6 & 69853.68 & 6967.5 & 19496 & 2170 \\
\hline
\end{tabular}
distribution using the thyseen Polygon method using GIS software. (Table 1) shows the data used for GIS mapping.

Table 1. Data for GIS Mapping. 


\begin{tabular}{|c|c|c|c|c|c|c|c|c|c|}
\hline \multicolumn{2}{|c|}{ COORDINAT } & \multirow{2}{*}{ ST } & \multirow{2}{*}{$\begin{array}{c}\text { AAR } \\
(\mathrm{mm} / \mathrm{yr})\end{array}$} & \multirow{2}{*}{$\begin{array}{c}\text { AATM } \\
\left({ }^{\circ} \mathrm{C}\right)\end{array}$} & \multirow{2}{*}{$\begin{array}{c}\text { AARH } \\
(\%)\end{array}$} & \multirow{2}{*}{$\begin{array}{l}\text { AAIRP } \\
\text { (MT) }\end{array}$} & \multirow{2}{*}{$\begin{array}{l}\text { AARRP } \\
(\mathrm{MT})\end{array}$} & \multirow{2}{*}{$\begin{array}{c}\text { AAIRY } \\
(\mathrm{MT} / \mathrm{Ha})\end{array}$} & \multirow{2}{*}{$\begin{array}{l}\text { AARRY } \\
(\mathrm{MT} / \mathrm{Ha}) \\
\end{array}$} \\
\hline $\mathbf{X}$ & $\mathbf{Y}$ & & & & & & & & \\
\hline 15.1852 & 120.5394 & Clark & 2048 & 27.2 & 75.5 & 291142 & 10796.36 & 67024.7 & 3269 \\
\hline 16.2277 & 122.0633 & Casiguran & 3770 & 26.8 & 88.12 & 68471 & 25445 & 18169 & 8109 \\
\hline 15.7589 & 121.5607 & Baler & 2187 & 26.7 & 85.6 & 67853.55 & 6766.5 & 18456 & 2070 \\
\hline
\end{tabular}

\section{RESULTS AND DISCUSSION}

\section{A. Time Series Analysis}

Annual, semi-annual, and quarterly time series graphs of rice yield for irrigated and rainfed ecosystem type of farming in Nueva Ecija (Figures 2a-2f) show an overall increasing trend from year 1991-2018. Although there are observed decline and fluctuations in the years in between which are possibly due to the effects of significant climate variabilities and climate change that may be observed during those years and the seasonality of rice production and changes in climate variables in Nueva Ecija which is further shown in the semiannual and quarterly (seasonal) time series graphs. The increasing trend is further shown by the positive slope of the equation of the 4-year/period smoothened rice yield trendlines for both irrigation and rainfed ecotype.

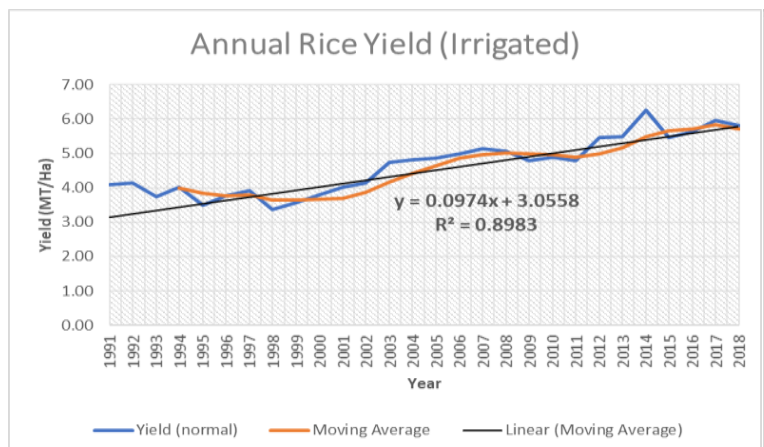

(a)

Semi-Annual Rice Yield (Irrigated)

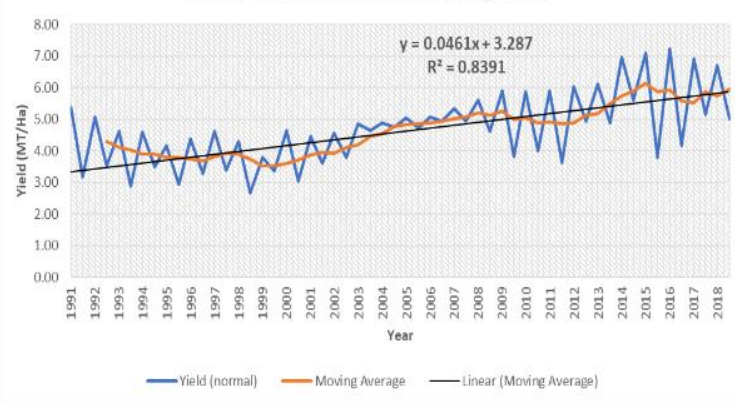

(c)

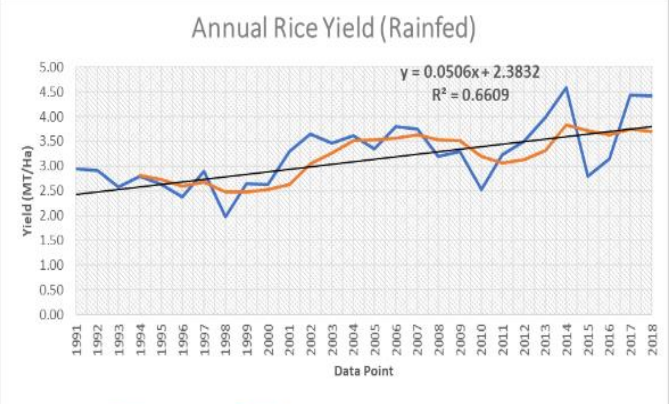

—Vied (normal) —Moving Average — Linear (Moving Averrge

(b)

Semi-Annual Rice Yield (Rainfed)

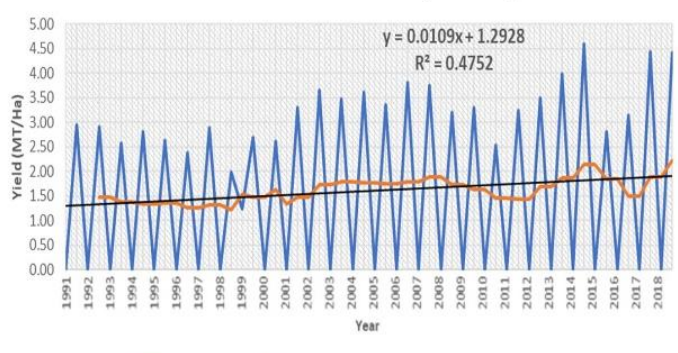

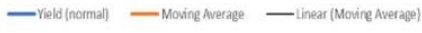

(d) 


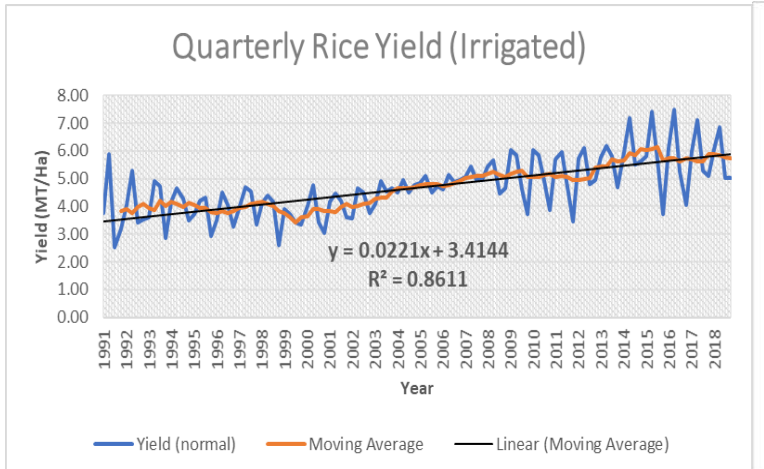

(e)

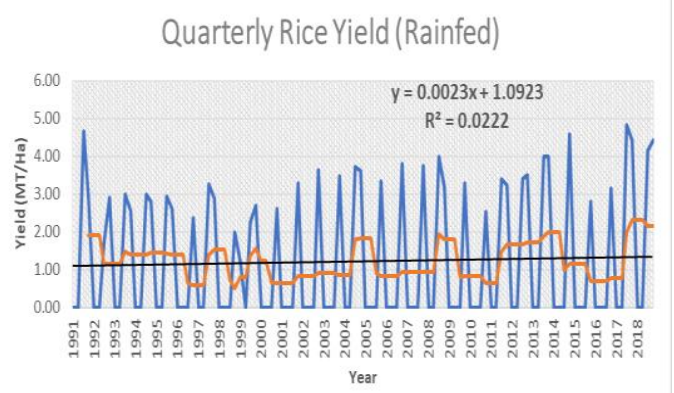

—Yield (normal) —Moving Average — Linear (Moving Average)

(f)

Fig. 2. Annual, semi-annual, and quarterly time series graphs of rice production for irrigated and rainfed ecosystem type of farming in Nueva Ecija.

On the other hand, the annual, semi-annual, and quarterly time series graphs for the different climate variables are shown in (Figures 3a to 3d). These figures show fluctuating trends and irregularities spanning from the year 1991 to 2018. However, results showed overall decreasing trend in relative humidity and increasing trends for rainfall, minimum temperature, and mean temperature. Increasing and decreasing trends were shown by the positive and negative slopes of the equations of the 4-year/period smoothened trendlines for the said climate variables.

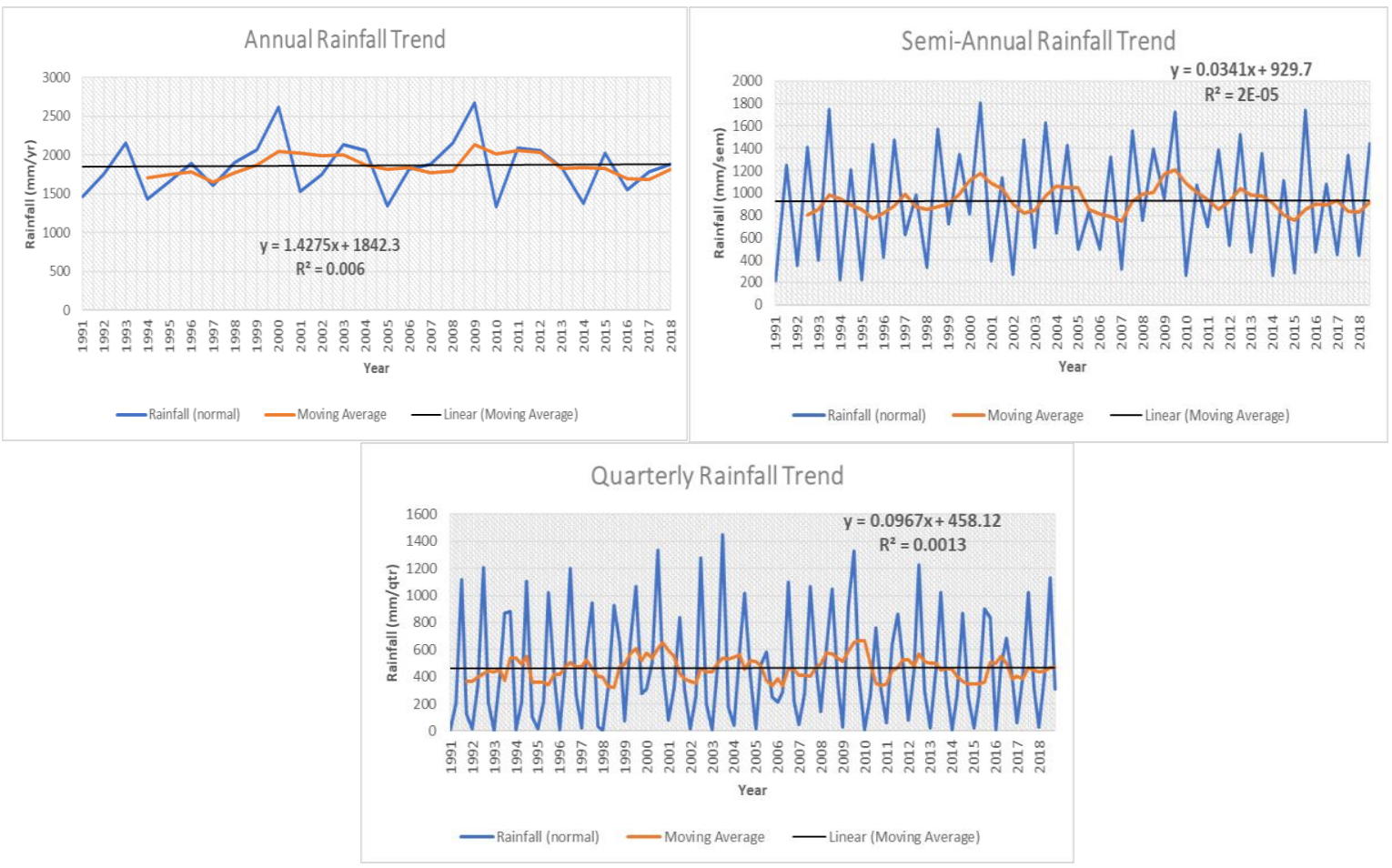

(a) 


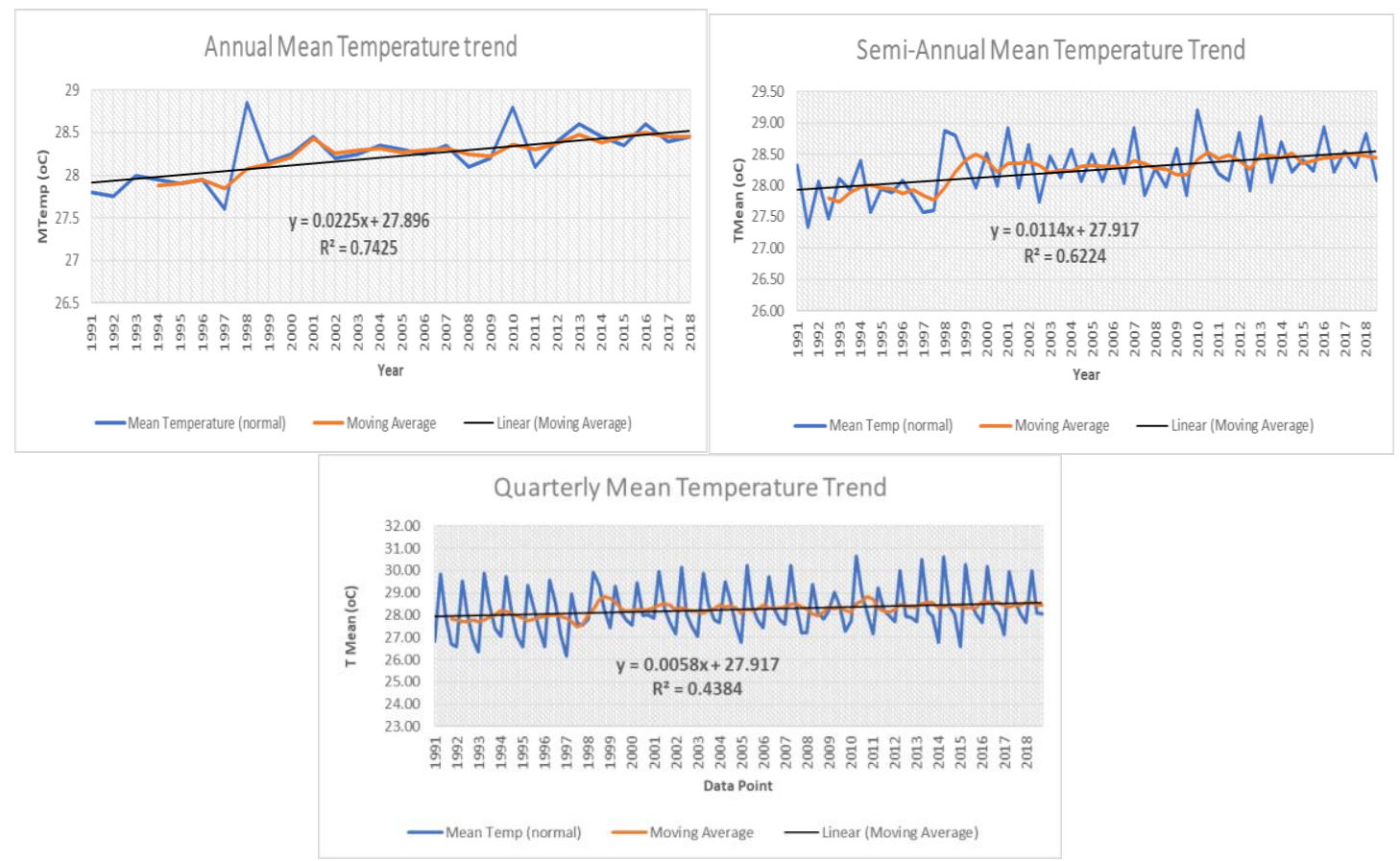

(b)

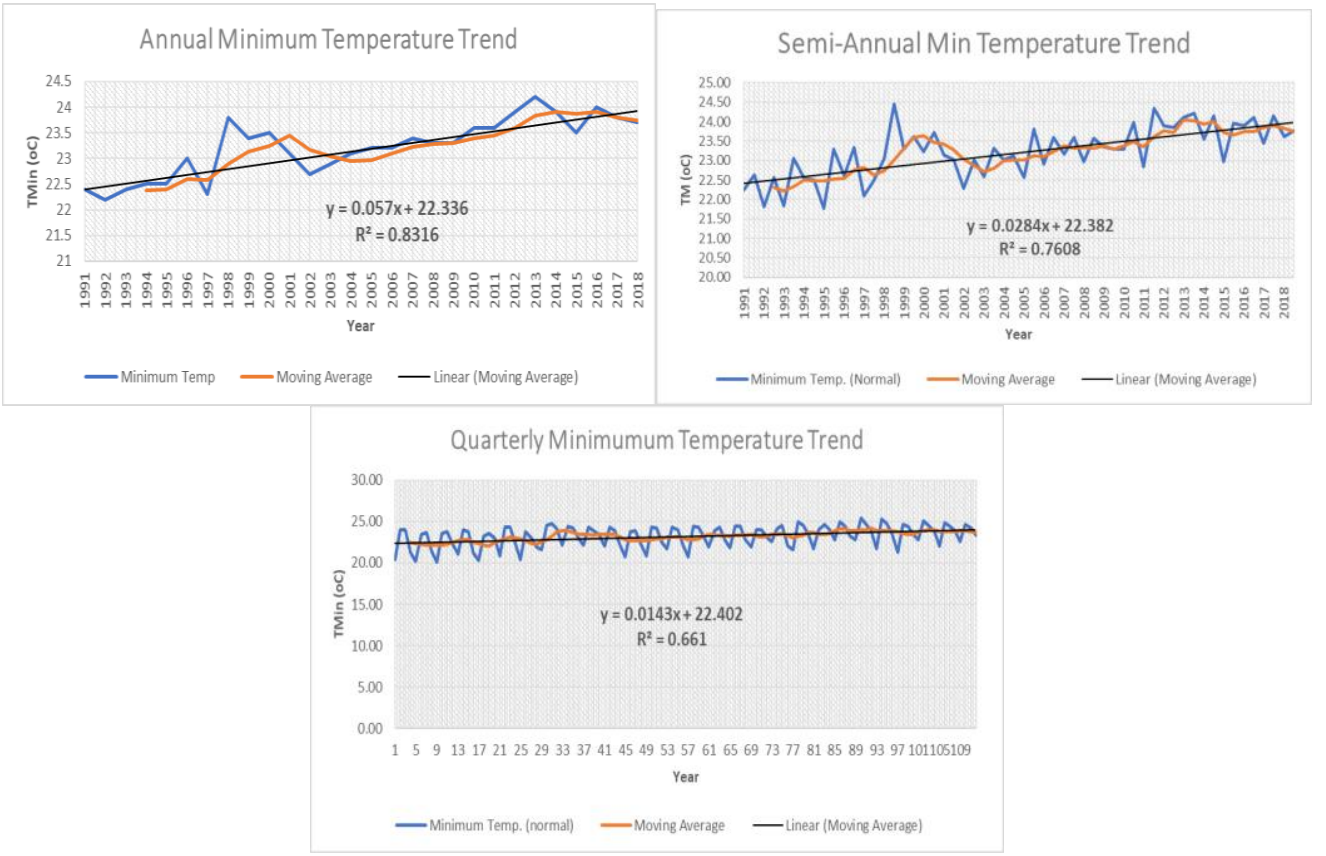

(c) 


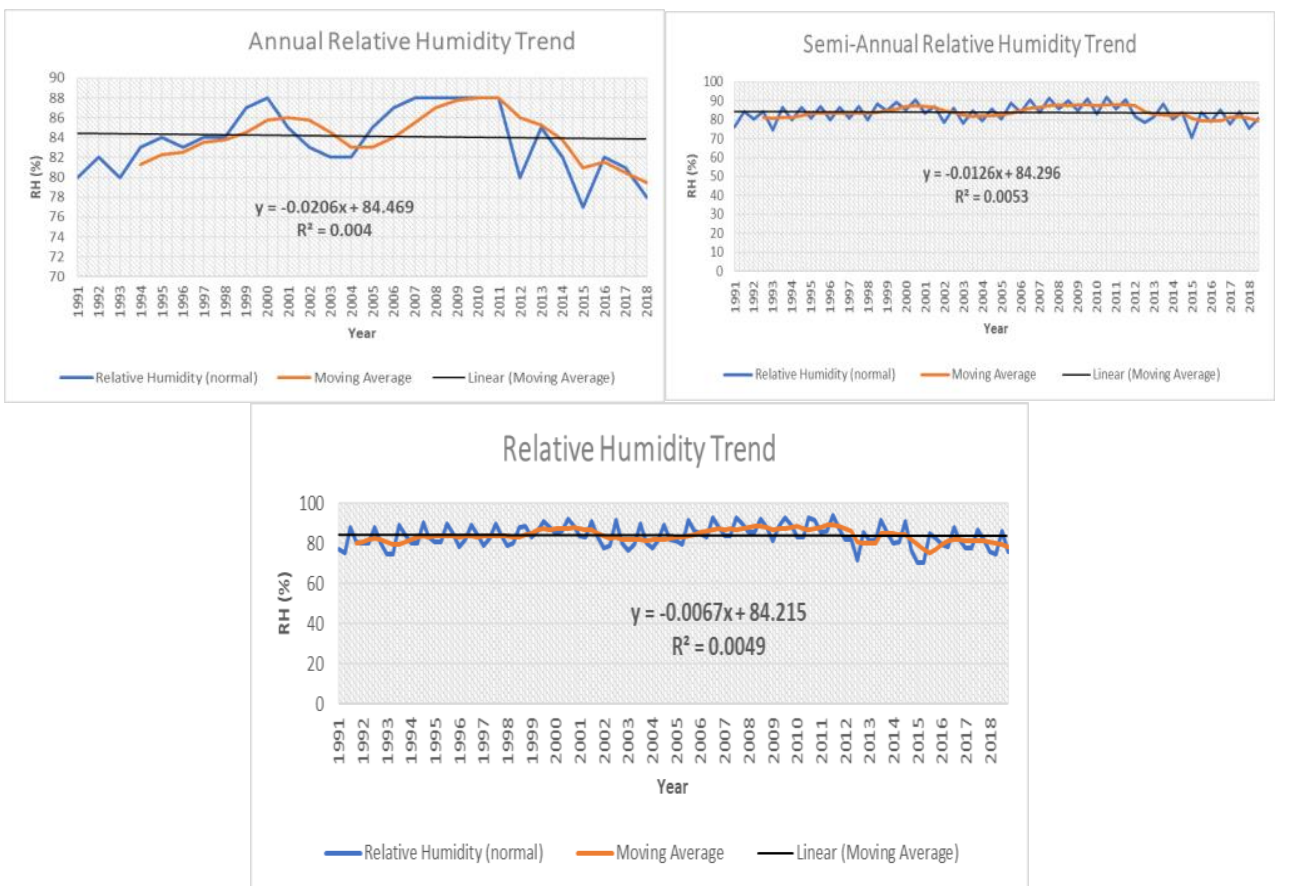

(d)

Fig. 3. Annual, semi-annual, and quarterly time series graphs of different climate variables - rainfall, mean temperature, minimum temperature, and relative humidity.

The fluctuations, irregularities and anomalies shown in the time series graphs of rice production and the different climate variables can be brought by different factors, one of which is climate change, this is supported by the results of research by Husein et.al. (2020) that in the current scenario of global climate change, the utmost desire to ensure food security is to maintain and increase agricultural production. But, due to rapid climate change, many abiotic factors such as rainfall, drought, flooding, temperature, and solar radiations are severely affecting the production of rice at various growth stages. Climate change brings climate variabilities to extremes such the case of El Niño and La Niña.
Figure 3 shows the rice production anomaly for irrigated and rainfed farming ecotype for Nueva Ecija from 1991-2018. From year 1991-2000, negative rice production anomalies were observed which means rice production during that time were lower than the baseline or average rice production based on 1988-2018 normal average rice production value. On the other hand, starting from year 20012018, positive rice production anomalies were observed which means that rice production is greater than the reference or baseline value (figure 2a-2f) and the trend in increasing.

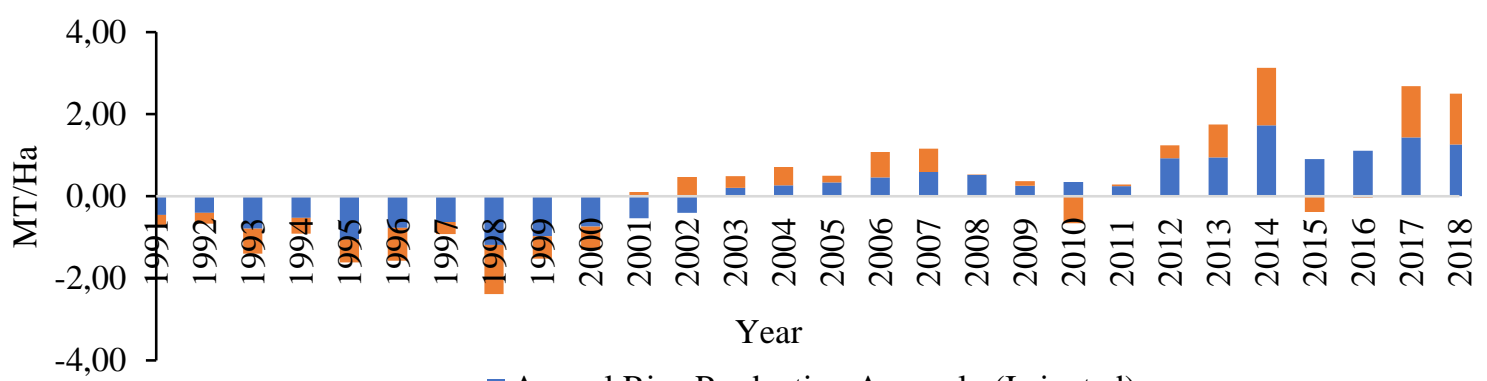

- Annual Rice Production Anomaly (Irrigated)

- Annual Rice Production Anomaly (Rainfed)

Fig. 4. Annual rice production anomaly for irrigated and rainfed ecosystem type of farming in Nueva Ecija from 1991-2018 based on 1988-2018 normal values. 
(Figures 5 and 6) show the annual rainfall and mean temperature anomalies from 1991-2018 in Nueva Ecija. For rainfall anomaly, we can see that there are fluctuations observed in such a way that positive and negative anomalies seem to happen and be observed almost alternately. But more negative anomalies were observed from the span of 19912018 which means that oftentimes there were decrease in the normal average annual rainfall value which could also mean that drought or El Niño may have happened more often than La Niña. This claim may also be justified by and can be seen in the annual mean temperature anomaly graph which shows a consistent positive mean temperature anomaly from year 1998-2018. The climate anomaly graphs are indeed showing the effects of global warming and climate change. Also, from the previous time series graphs, we can see that annual mean temperature graph shows increasing linear trend with $\mathrm{r}^{2}$ value for the linear 4-year smoothened trend of 0.7425 which is considerably high. Also, the annual minimum temperature shows an increasing linear trend with $\mathrm{r}^{2}$ value of 0.8316 which could mean that the normal minimum temperature has already increased caused by continuous warming of the Earth. Annual time series graph for rainfall also seemed to show a general increasing linear trend, however its $\mathrm{r}^{2}$ value is considerably small which means that linear forecasting is not really reliable for rainfall and that the trend is generally a fluctuating trend.

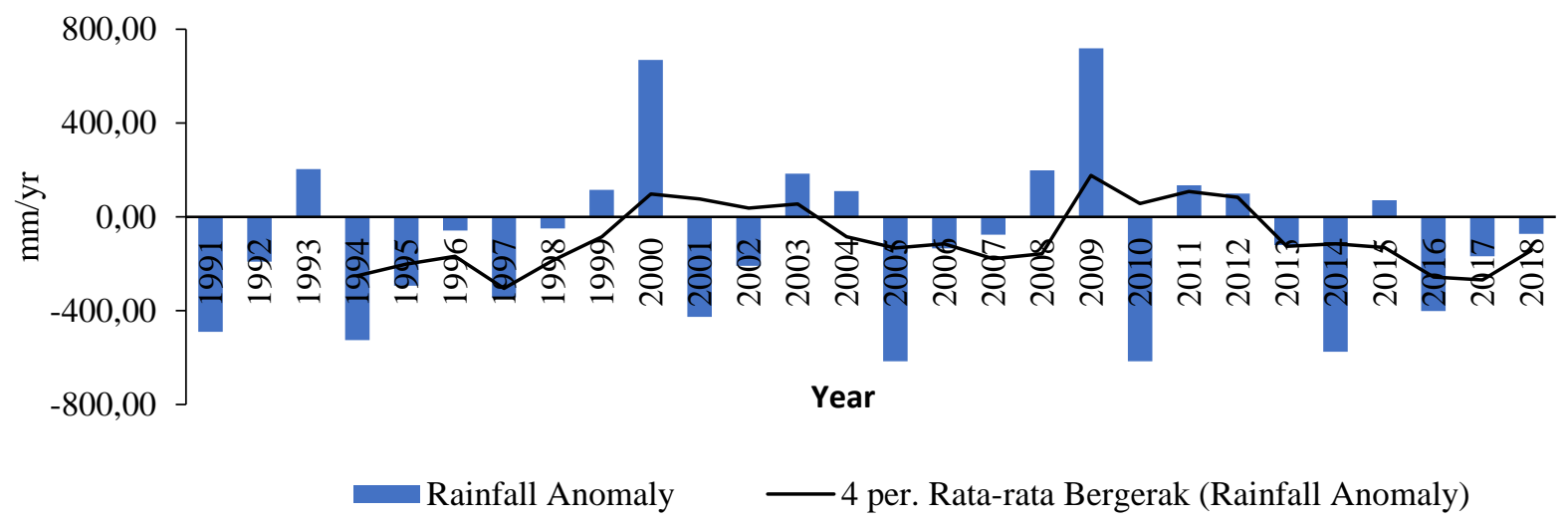

Fig. 5. Annual rainfall anomaly in Nueva Ecija from 1991-2018 based on 1985-2015 normal values.

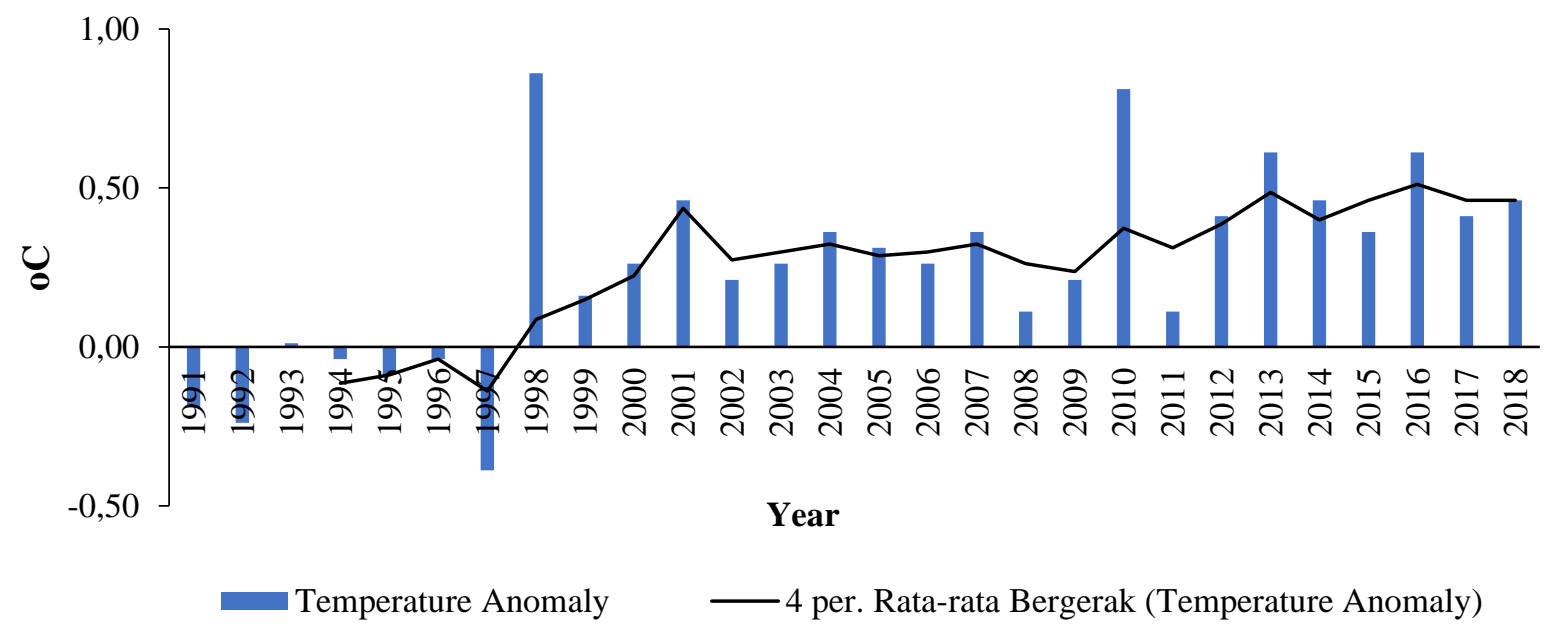

Fig. 6. Annual mean temperature anomaly in Nueva Ecija from 1991-2018 based on 1985-2015 normal values. 
Table 2 shows the occurrence of El Niño and La Niña from the year 1952-2019 and their corresponding intensities (NOAA, 2019). Based on Figures $2 a-2 f$, it can be seen that there is a large decrease in rice production in Nueva Ecija for both irrigated and rainfed ecotypes from year $1998-2000$, this occurred was caused by an extreme climate such as the El Niño and La Niña. This can be attributed to the large increase in the rainfall and mean temperature trends during the said years. From Table 2, it can be noted that there are occurrences of strong El Niño and weak and strong $\mathrm{La}$ Niña corresponding to year 1998-2000. According to
Arini et al. (2011) In the El Nino event, the availability of water for agriculture decreases so the crop production and productivity decreases. Meanwhile, in the La Nina incident, the availability of water could become excessive and cause flooding resulting in crop failures. Both of these climate anomalies are known to have caused damage to rice plants, thus affecting rice production and Chung et al. (2015) stated that the occurrence of seasonal anomalies such as El Niño and La Niña, especially in 2000 and 2009 has caused the loss of agricultural products, especially rice production.

Table 2. The Oceanic Niño Index (ONI), the running 3-month mean SST anomaly for the Niño 3.4 region (i.e., $5^{\circ} \mathrm{N} 5 \mathrm{~S}$, $120^{\circ}-170^{\circ} \mathrm{W}$ ), is NOAA standard for identifying El Niño (warm) and La Niña (cool) events in the tropical Pacific.

\begin{tabular}{ccccccc}
\hline \multicolumn{3}{c}{ El Nino } & \multicolumn{3}{c}{ La Nina } \\
\hline Weak & Moderate & Strong & \multirow{2}{*}{ Very Strong-3 } & Weak & Moderate & Strong \\
-11 & -7 & -5 & $1982-83$ & $1954-55$ & $1955-56$ & $1973-74$ \\
\hline $1952-53$ & $1951-52$ & $1957-58$ & $195-4$ & $1975-76$ \\
$1953-54$ & $1963-64$ & $1965-66$ & $1997-98$ & $1964-65$ & $1970-71$ & $1988-89$ \\
$1958-59$ & $1968-69$ & $1972-73$ & $2015-16$ & $1971-72$ & $1995-96$ & $1998-99$ \\
$1969-70$ & $1986-87$ & $1987-88$ & & $1974-75$ & $2011-12$ & $1999-00$ \\
$1976-77$ & $1994-95$ & $1991-92$ & & $1983-84$ & & $2007-08$ \\
$1977-78$ & $2002-03$ & & & $1984-85$ & & $2010-11$ \\
$1979-80$ & $2009-10$ & & & $2000-01$ & & \\
$2004-05$ & & & & $2005-06$ & & \\
$2006-07$ & & & $2008-09$ & & \\
$2014-15$ & & & $2016-17$ & & \\
$2018-19$ & & & & $2017-18$ & & \\
\hline
\end{tabular}

Source: (NOAA, 2019)

\section{B. Correlation Analysis}

Correlation test using annual, semi-annual, and quarterly data of rice yield and various climate variables were done to examine the relationship and effects of climate variables on both irrigated and rainfed farming system of rice production. According to Sugiyono (2010), the value of Rsquared at the interval of 0.20 to 0.399 has a low correlation, 0.40 to 0.599 has a moderate correlation, 0.60 to 0.799 has a strong correlation, and 0.80 to 1.00 has a very strong correlation. Therefore, based on the correlation analysis using annual data (see Table 3), we found that only the variable of minimum temperature has a strong correlation with the negative relationship to the yield of irrigated farming rice system. Other variables were having low and moderate correlations both to the yield of irrigated and rainfed farming systems. The results are similar with the correlation analysis using quarterly data shown by Table 5. On the other hand, strong correlation results were mostly found in the correlation analysis using semi-annual data. Table 4 shows that the correlation between the yield of irrigated rice farming system to the rainfall, mean temperature, and relative humidity were having strong correlations, whereas rainfall and minimum temperature were having very strong correlations to the yield of rainfed farming system. The findings were supported by a study from Khanal (2015) and Oguntunde et al. (2018) where they found rice yield is influenced by climate variables including total annual rainfall, annual average maximum temperature, and annual average minimum temperature, which rice yield and minimum temperature have a strong correlation features compared to other climate variables. 
Table 3. Correlation between rice yield and climate variables using the annual data.

\begin{tabular}{ccc}
\hline \multirow{2}{*}{ Climate Variables } & \multicolumn{2}{c}{ Correlation to Yield (r) } \\
\cline { 2 - 3 } & Irrigated & Rainfed \\
\hline Rainfall & -0.1064 & -0.1101 \\
TMean & 0.4582 & 0.2313 \\
TMin & -0.6304 & -0.4014 \\
RH & -0.2270 & -0.1692 \\
\hline
\end{tabular}

Table 4. Correlation between rice yield and climate variables using the semi-annual data.

\begin{tabular}{ccc}
\hline \multirow{2}{*}{ Climate Variables } & \multicolumn{2}{c}{ Correlation to Yield $(\mathrm{r})$} \\
\cline { 2 - 3 } & Irrigated & Rainfed \\
\cline { 2 - 3 } Rainfall & -0.5917 & 0.8591 \\
TMean & 0.5753 & -0.5997 \\
TMin & 0.2714 & 0.8297 \\
RH & -0.5611 & 0.6267 \\
\hline
\end{tabular}

Table 5. Correlation between rice yield and climate variables using the quarterly data.

\begin{tabular}{ccc}
\hline \multirow{2}{*}{ Climate Variables } & \multicolumn{2}{c}{ Correlation to Yield (r) } \\
\cline { 2 - 3 } & Irrigated & Rainfed \\
\hline Rainfall & -0.1150 & 0.2256 \\
TMean & 0.4759 & -0.2828 \\
TMin & 0.0462 & -0.4604 \\
RH & -0.2816 & 0.2463 \\
\hline
\end{tabular}

Using semi-annual or seasonal data is actually much better since using annual data tend to mask and may not show the seasonality in rice yield which corresponds to climate and weather seasonality. On the other hand, quarterly data may have super imposed, misrepresent, and exaggerate the said seasonality in rice yield and climate since Nueva
Ecija really exhibits only 2 season types yearly as shown in (figure 7) the monthly average rainfall for Nueva Ecija from 1991-2018. That is, from December to April there is dry season and low rainfall, and wet or rainy season happens from May to November with maximum rain period from JuneSeptember (WAMIS, 2019).

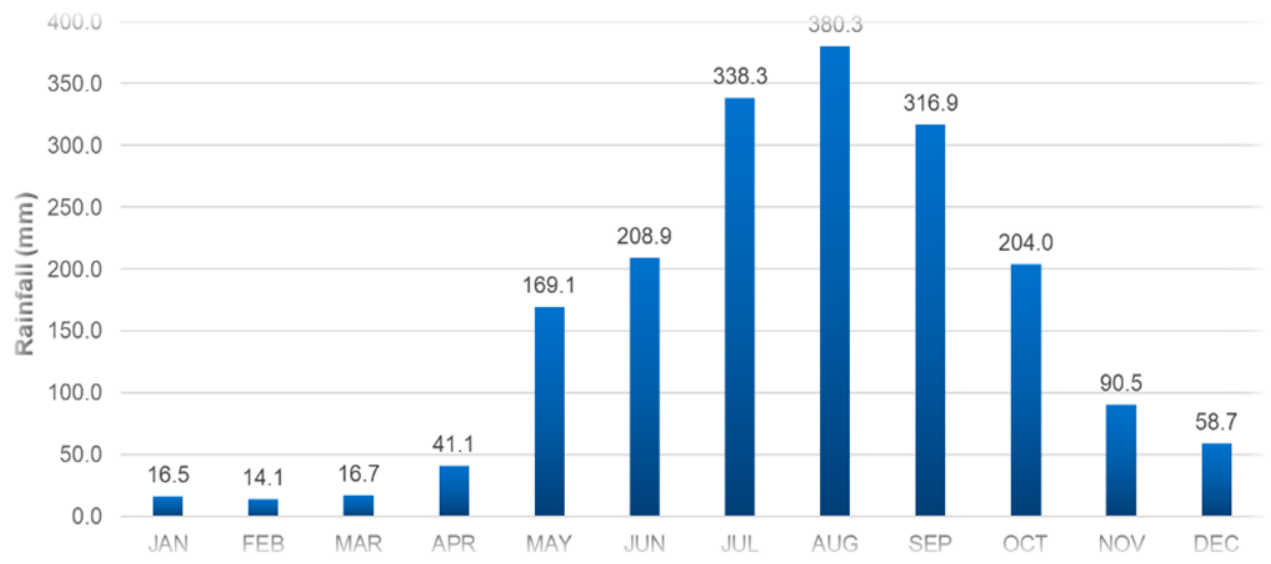

Fig. 7. Monthly average precipitation (mm/month) in Nueva Ecija, Philippines from 1991-2018 


\section{GIS Mapping}

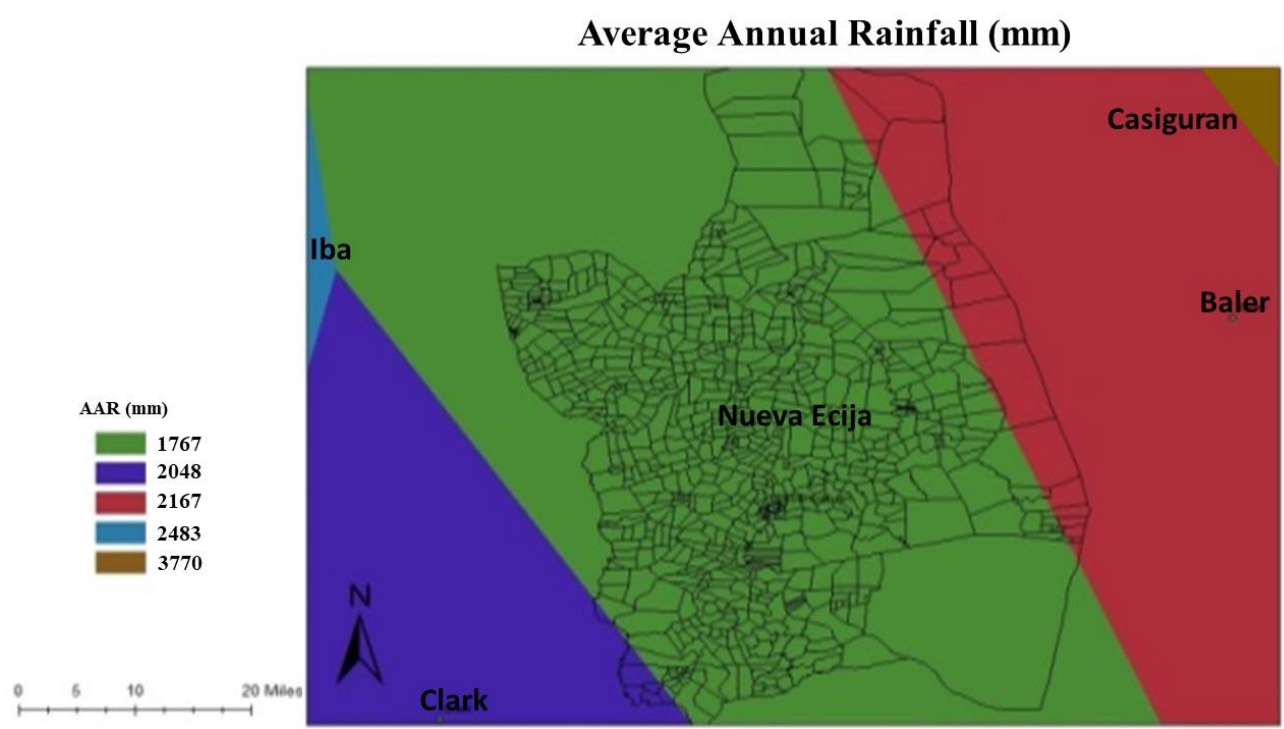

(a)

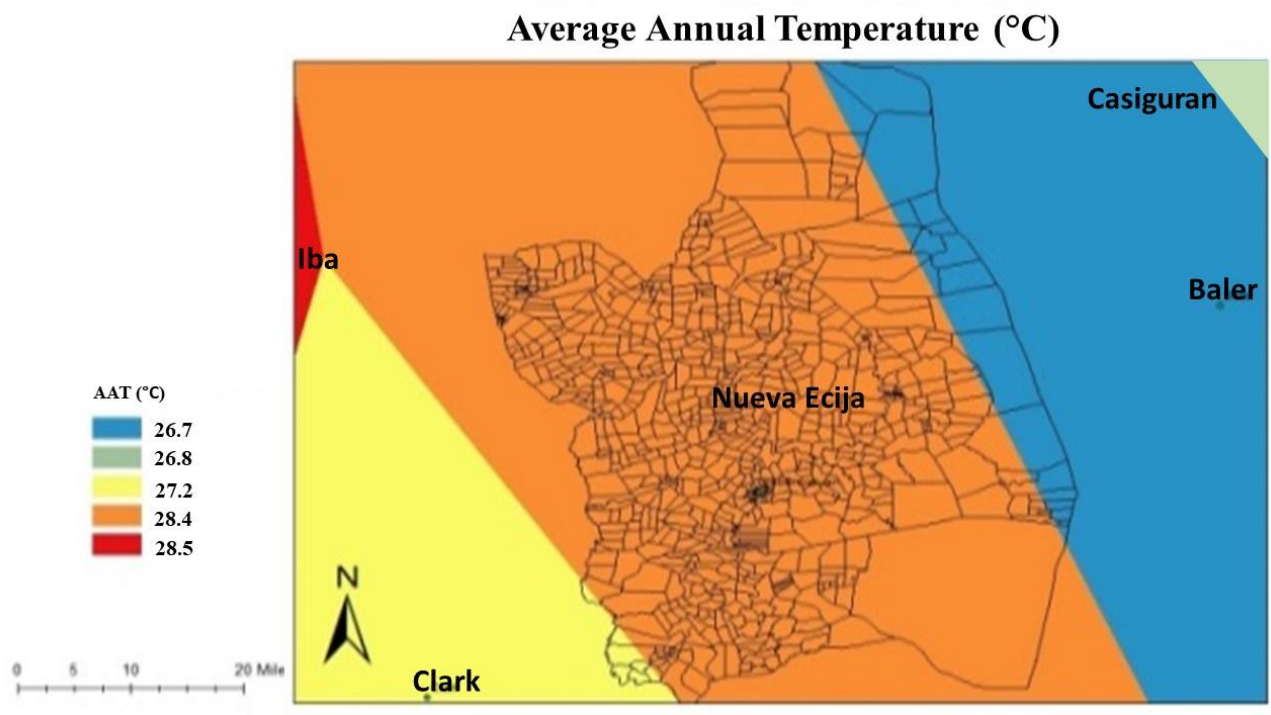

(b) 


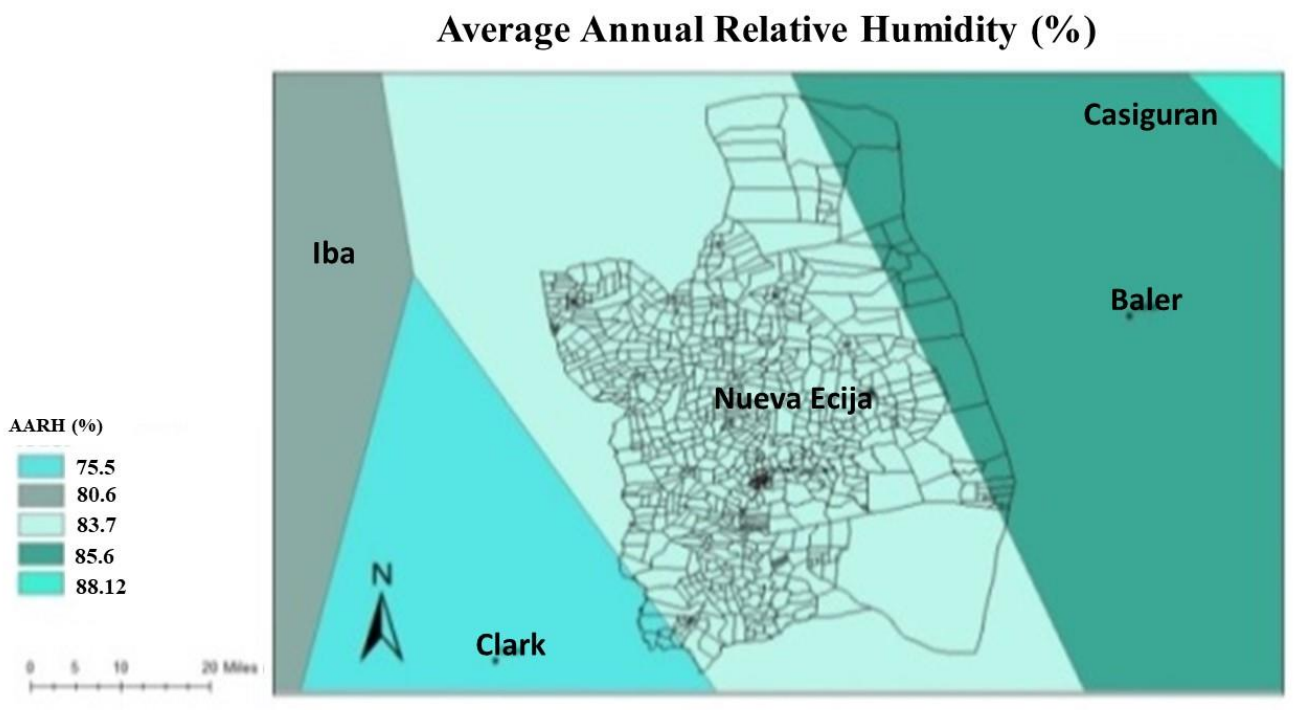

(c)

Fig. 8. Average annual rainfall (a), average annual temperature (b) and average annual relative humidity (c)

According to Figure 8 (a), (b) and (c) the average annual rainfall and humidty results for the years 1991-2018 in Nueva Ecija showed the lowest compared to other provinces in Central Luzon, with rainfall and humidity values ranging between 1767 $2167 \mathrm{~mm}$ and $75-84 \%$, respectively. whereas in the other areas of Clark, Baler and Casiguran the values of rainfall and humidity ranged from $2048-3770 \mathrm{~mm}$ and $81-88 \%$, respectively. The average temperature in Nueva Ecija is higher than Clark, Baler and Casiguran but lower than the temperature in Zambales with a value of $28.4{ }^{\circ} \mathrm{C}$. However, some areas have a fairly low average such as Nueva Ecija in the northern region bordering Clark and Nueva Ecija in the southern region bordering Baler.

\section{Average Annual Rainfed Rice Production (MT)}

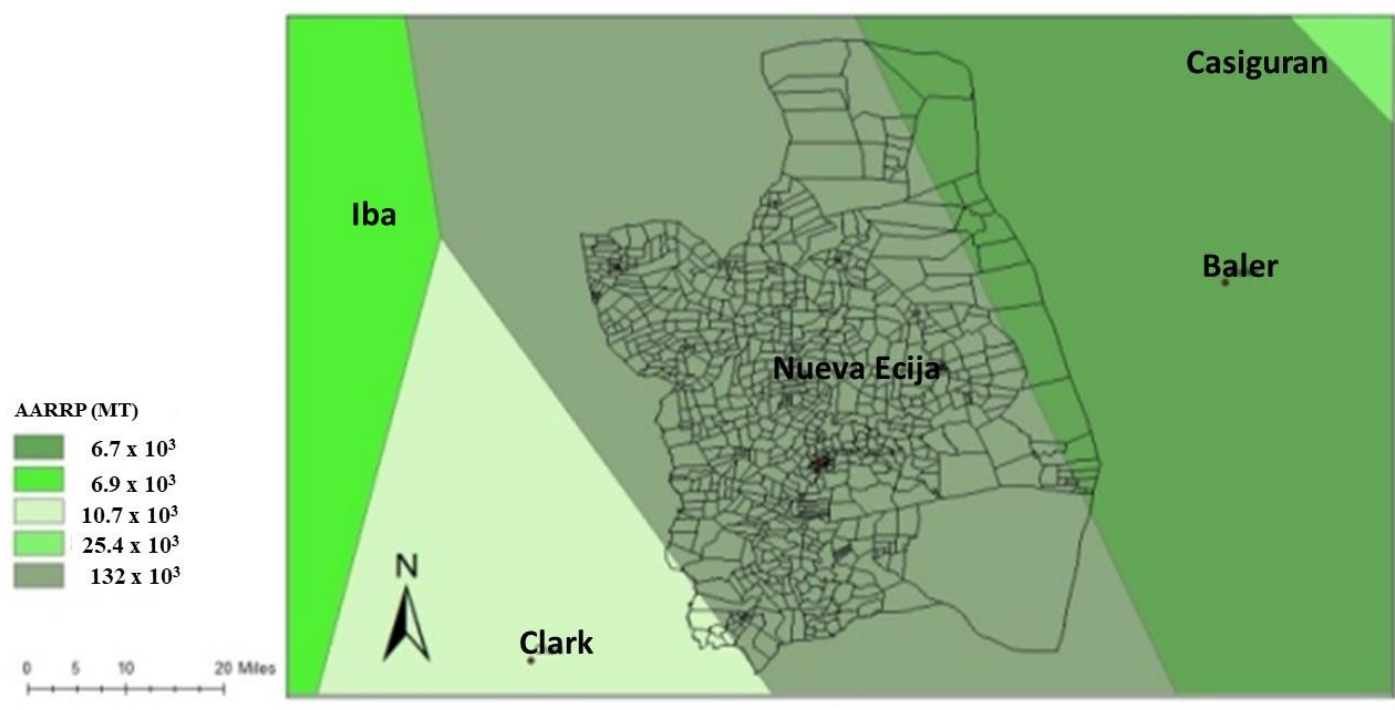

(a) 


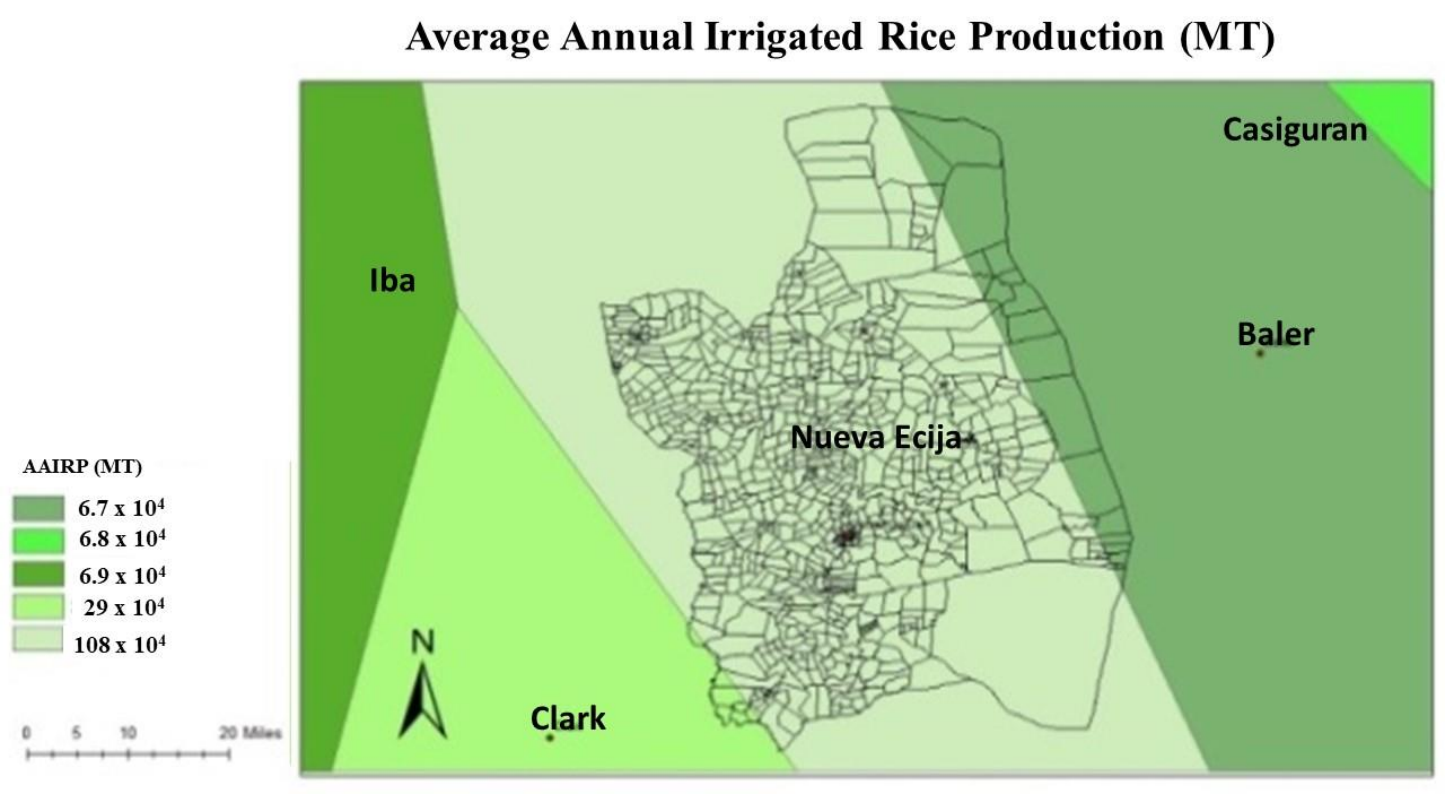

(b)

Fig. 9. Average annual rainfed rice production (a) and Average annual irrigated rice production (b)

Figures 16 (a) and (b) show average of annual rainfed rice production mapping and average of annual irrigated rice production mapping (MT). The results showed that the highest average annual rice production is irrigation (a) and rainfed (b) produced by Nueva Ecija Province with a rice production value of $108 \times 10^{4}(\mathrm{MT})$ for irrigation and $132 \times 10^{3}$
(MT) for rainfed, while for In other areas, rice production values are in the range of $6.7 \times 10^{4}$ $29 \times 10^{4}(\mathrm{MT})$ for irrigation and $6.7 \times 10^{3}-25.4 \times 10^{3}$ (MT) for rainfed and the amount of average annual irrigated rice production in all areas is higher than rainfed.

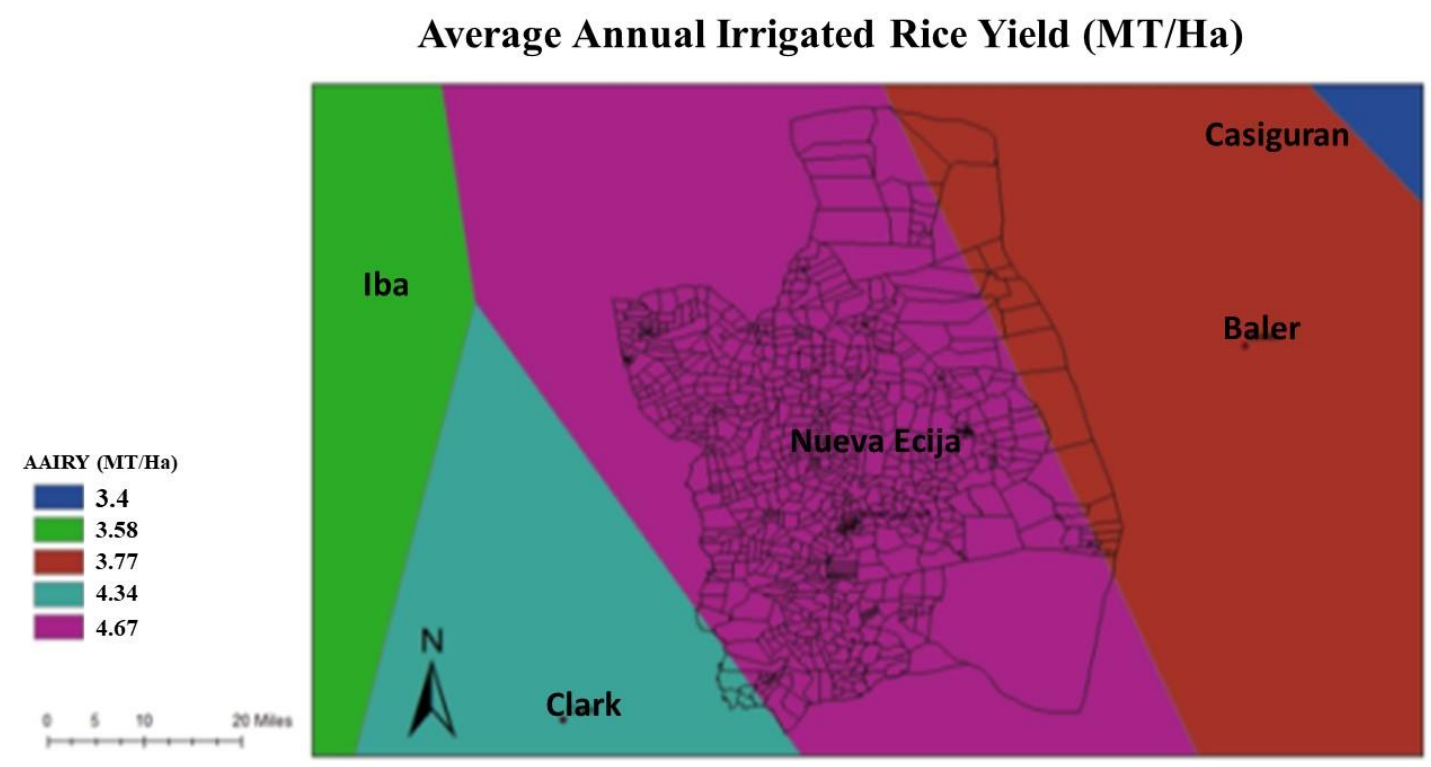

(a) 


\section{Average Annual Rainfed Rice Yield (MT/Ha)}

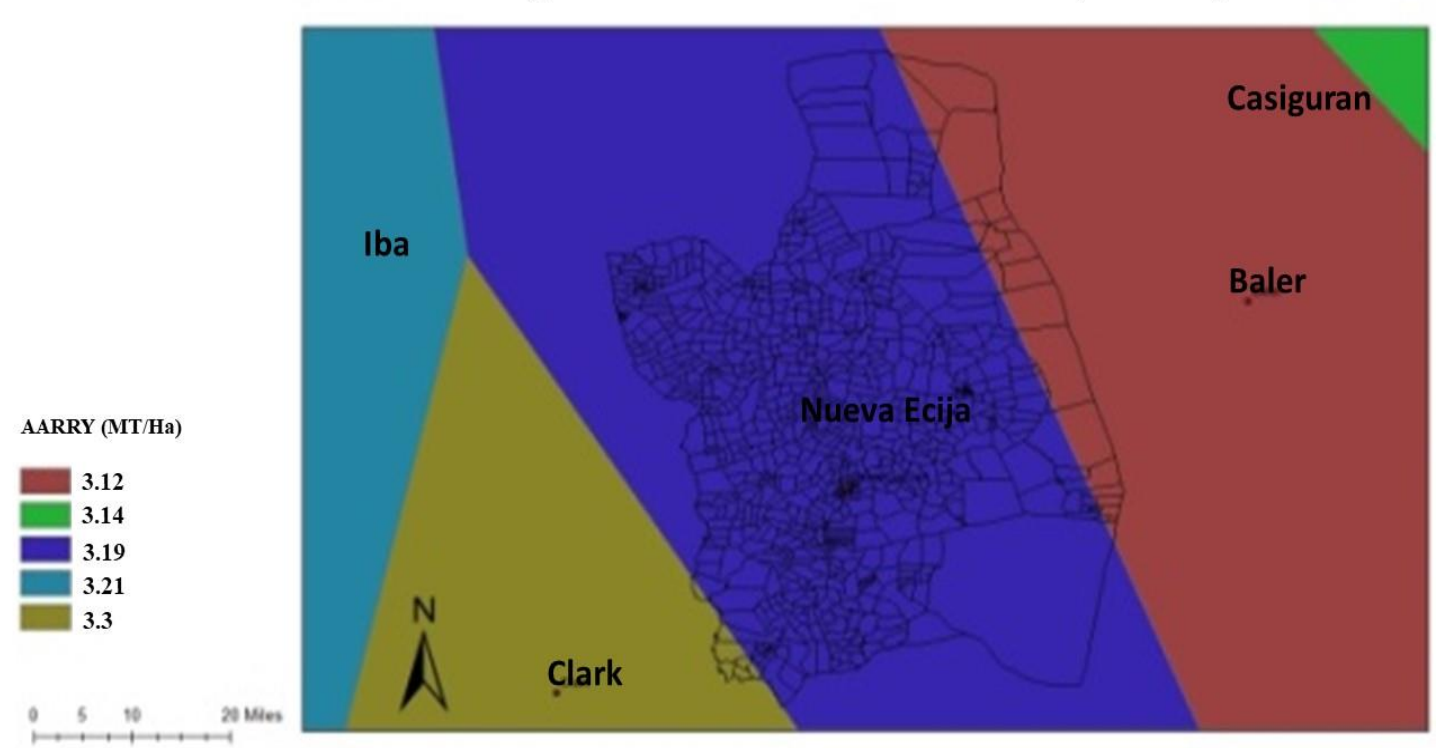

(b)

Fig. 10. Average annual irrigated rice yield (a) and average annual rainfed rice yield (b)

Figure 10 (a) and (b) showed that average annual irrigated rice yield mapping and Average annual rainfed rice yield mapping in Metric Tons per hectare (MT / Ha). The results show that the highest average annual irrigated (a) and rainfed (b) rice

\section{CONCLUSION}

This study shows the effect of the different climate variables in rice crop yield in both irrigated and rainfed ecotype farming system in Nueva Ecija, Philippines. The following are the conclusions derived from the results of the study:

1. Rice yield for irrigated and rainfed ecosystem type of farming in Nueva Ecija show an overall increasing trend from year 1991-2018, although there are observed decline and fluctuations in some years.

2. The different climate variables show fluctuating trends and irregularities spanning from the year 1991-2018. But it showed overall decreasing trends for both minimum temperature and relative humidity and increasing trends for rainfall and annual mean temperature. yielded by the Nueva Ecija province. When compared to the average annual rice yield irrigated and rainfed, the amount of productivity with irrigated in Nueva Ecija is higher than rainfed.

3. There are significant correlations between rice yield the all the climate variables in both irrigated and rainfed farming ecosystem types. For irrigated ecotype, rainfall and relative humidity have negative correlation to yield while both positive correlation for mean temperature and minimum temperature. On the other, for rainfed ecotype, rainfall, minimum temperature, and relative humidity have positive correlation to yield while negative correlation for mean temperature only.

4. Based on GIS mapping, Nueva Ecija is reported for having low average annual rainfall and relative humidity. However, the average annual rice production and yield in both irrigated and rainfed farming systems were found as the highest compared to the other province in Central Luzon during the period of 1991 to 2018. 


\section{REFERENCES}

[PSA] Philippines Statictic Authority 2009. Selected Statistics on Agriculture 2019. Diliman, Quezon City, Philippines: Philippine Statistics Authority;Link:https://psa.gov.ph/sites/default/ files/Selected\%20Statistics\%20on\%20Agricult ure\%202019.pdf; 2019 [Accessed on October 12 2019]

[PSA] Philippines Statictic Authority. 2009. OpenSTAT/ Agriculcure, Forestry, Fisheries/ Crops. Diliman, Quezon City, Philippines: Philippine Statistics Authority; Link: http://openstat.psa.gov.ph/[Accessed on October 27 2019]

[WAMIS] World AgroMeteorological Informarmation Service. 2019. Link http://www.wamis.org/ [Accessed on October 30 2019].

Battisti, D.S., Naylor, R.L. 2009. Historical warnings of future food insecurity with unprecedented seasonal heat. Journal of Science. 323: 240-244.

Bell, M.A., Fischer, R.A., Byerlee, D., Sayre. K. 1995. Genetic and agronomic contributions to yield gains: A case study for wheat. Journal of Field Crops Research. 44: 55-65.

Iizumi, T., Ramankutty. N. 2016. Changes in yield variability of major crops for 1981-2010 explained by climate change. Journal of Environmental Research Letters 11: p.034003.

Lansigan, F. P., De Los Santos, W. L., Coladilla, J.O. 2000. Agronomic impacts of climate variability on rice production in the Philippines. Agriculture, Ecosystems and Environment, 82 (1-3), $129-137$.

Lesk, C., Rowhani, P., Ramankutty. N. 2016. Influence of extreme weather disasters on global crop production. Journal of Nature. 529: 84-87.

Lobell, D., B. 2010. Crop responses to climate: timeseries models. In: Lobell D, Burke M, editors. Journal of Climate Change \& Food Security. Springer Netherlands. p 85-98.

Lobell, D.B., Cahill, K.N., Field. C.B., 2007. Historical effects of temperature and precipitation on California crop yields. Journal of ClimChange . 81(2):187-203.
Lobell, D.B., Field. C.B. 2007. Global scale climatecrop yield relationships and the impacts of recent warming. Journal of Environ Res Lett 2(1): 014002

Matthews, R.B., Wassmann, R. 2003. Modelling the impacts of climate change and methane emission reductions on rice production: A review. Eur. J. Agron., 19: 573-598.

Osborn, T.M., Wheeler. T.R. 2013. Evidence for a climate signal in trends of global crop yield variability over the past 50 years. Journal of Environ Res Lett. 8(2): 024001.

Ricepedia. Rice as a Crop. Link: http://ricepedia.org/rice-as-a-crop

[Accessed on October 27 2019]

Sajid. H, Jie. H, Jung. H, Shakeel. A, Satyabrata. N, Sumera. A, Awais. S, Chunquan. Z, Lianfeng. Z, Xiaochuang. C, Qianyu. J, Junhua. Z. 2020. Rice Production Under Climate Change: Adaptation and Mitigation Strategies, Environment, Climate, Plant and Vegetation Growth,pp 659-686.

Salvacion, A. R. 2019. Effect of climate on provincial-level banana yield in the Philippines. Information Processing in Agriculture, (xxxx). https://doi.org/10.1016/j.inpa.2019.05.005

Specht, J.E., Hume, D.J., Kumudini, S.V. 1999. Soybean yield potential genetic and physiological perspective. Journal of Crop Science 39: 1560-1570.

Tollenaar, M., Lee, E.A. 2002. Yield potential, yield stability and stress tolerance in maize. Field Crops Research. 75: 161-169.

UNESCO. https://www.gounesco.com/palayancity-a-hidden-gem-in-nueva-ecija/ [Accessed on October 10 2019]

Urban. D.W., Sheffield. J., Lobell. D.B., 2015. The Impacts of Future Climate and Carbon Dioxide Changes on the Average and Variability of US Maize Yields under Two Emission Scenarios. Journal of Environmental Research Letters. 10: 045003. 
Utami. A.W., Jamhari, Hardyastuti. S. 2011. El Nino, Lanina, dan Penawaran Pangan di Jawa. Indonesia. Jurnal Ekonomi Pembangunan, Vol. 12, No. 2: 257-271.

Khanal. B. 2015. Correlation of Cliamtic Factors with Cereal Crops yield: A Study from Hirostical Data of Morang District, Nepal. The Journal of Agriculture and Environment Vol: 16, June 2015.
Oguntunde . P. G., Lischeid. G., Dietrich. O. 2018. Relationship between Rice Yield and Climate Variables in Southwest Nigeria Using Multiple Linear Regression and Support Vector Machine Analysis. Int J Biometeorol 62, 459-469 (2018). https://doi.org/10.1007/s00484-017-1454-6 